IJMS 17 (Special Issue), 51-61 (2010)

\title{
GLOBAL FINANCIAL CRISIS: LESSONS LEARNED
}

\author{
NOR HAYATI AHMAD \\ UUM College of Business \\ Universiti Utara Malaysia
}

\begin{abstract}
A financial crisis appears to occur in a certain pattern; it usually starts with a rally of bank credits against a backdrop of easier monetary policy, ample liquidity, and more relaxed banking regulations. Such financial environment stimulates excess leverage to fund assets in real estates and housing in which consumers take advantage of cheap money and borrow heavily, while bankers zealously lend out in order to achieve high loan growth targets. As with all levered instruments, this practice generates great profits when the asset value rises. In contrast, it produces great losses when the assets fall in value, forcing lenders to ration credits and to compete aggressively for funds to cover the resultant losses. Retrospectively, the Global Financial Crisis exhibits far reaching implications from the excessive leverage, deregulation and from the spiral effects of globalisation, financial speculation, product innovation, moral hazards, and incentives problems. This paper reflects how similar or different the Global Financial Crisis is from the past crises in terms of its causes and manifestations, how Malaysia was impacted, and what key lessons could be learned from it.
\end{abstract}

Keywords: Financial crisis; risk taking and banking.

\section{Introduction}

A financial crisis is a regular incidence in the world. The term financial crisis is often associated with situations in which banks or financial institutions experience significant fall in their asset value, to such an extent that they face the probability of huge income losses or in worse cases, insolvency. Banking assets such as loans, stocks and shares, securities, and money market instruments are subject to price risk, causing their market values and income to fluctuate in varying market situations. Loans or mortgages for example, would 
not generate interest income to the lending banks if there are large loan defaults by their borrowers. The inability to service loans occurs when borrowers take large amounts of debts, in excess of their equity or their means to pay. This is made worse when there are sharp increases in cost of funds as bankers increased their lending rates during credit rationing and compete aggressively for funds to cover losses (Benn, 2009). Conversely, in situations where there is ample or excess liquidity in the financial system, credits are readily and easily available for investments in stock and shares, real estates or housing, or other financial instruments. It is also during easy money periods that regulators relax the regulations to ensure funds are transmitted into the economy and fully mobilised so that inflation is within control. Driven by economic buoyancy in such situation and prospects of higher profits as asset prices increase, people tend to indulge in excessive leverage and speculative activities. As with all levered (debt-based) instruments, this practice generates high profits when the asset value rises. However, it produces great losses when the assets fall in value during market crash or financial crisis (Benn, 2009). In most financial crises, excessive leverage and speculative elements are among the roots of financial losses leading to contractions in economic activities.

Table 1 shows the list of major financial crises in the world. Many of these crises were connected with stock market crash and bank lending defaults. Figure 1 provides an illustration of the financial crises and some of the contributory factors to the crises.

Table 1

List of Financial Crisis (1930-2009)

\begin{tabular}{lll} 
Year & \multicolumn{1}{c}{ Crisis } & \multicolumn{1}{c}{ Description } \\
$1930 \mathrm{~s}$ & $\begin{array}{l}\text { The Great } \\
\text { Depression }\end{array}$ & $\begin{array}{l}\text { The largest economic depression in the 20th } \\
\text { century. Triggered by stock market crash on } \\
\text { 29 Oct 1929. Spread to almost all countries in } \\
\text { the world. }\end{array}$ \\
1973 & $\begin{array}{l}\text { Oil prices soared, causing the 1973-74 stock } \\
\text { market crash }\end{array}$ \\
& $\begin{array}{l}\text { Latin American } \\
\text { Debt Crisis }\end{array}$ & $\begin{array}{l}\text { Large debts borrowed by Latin countries. } \\
\text { interest rates in the US increased significantly. }\end{array}$
\end{tabular}

(continued) 


\begin{tabular}{|c|c|c|}
\hline Year & Crisis & Description \\
\hline 1987 & Black Monday & $\begin{array}{l}\text { The largest one-day percentage decline in } \\
\text { the stock market history. Stock market crash } \\
\text { began in Japan, spread to Europe, USA and } \\
\text { other countries. }\end{array}$ \\
\hline 1989-1990 & $\begin{array}{l}\text { USA Loan } \\
\text { crisis }\end{array}$ & $\begin{array}{l}\text { United States Saving and Loan Industry } \\
\text { Crisis resulting in USD153 billion losses from } \\
\text { mismanagement in asset-liability interest rate } \\
\text { structures. }\end{array}$ \\
\hline 1990 & $\begin{array}{l}\text { Japan Banking } \\
\text { Crisis of 1990s }\end{array}$ & $\begin{array}{l}\text { Japanese asset price bubble due to heavy } \\
\text { speculative activities, deregulations leading } \\
\text { to the banking crisis }\end{array}$ \\
\hline 1992-1993 & $\begin{array}{l}\text { Black } \\
\text { Wednesday }\end{array}$ & $\begin{array}{l}\text { Speculative attack on currencies in the } \\
\text { European Exchange Rate Mechanism }\end{array}$ \\
\hline 1994-1995 & $\begin{array}{l}\text { Economic } \\
\text { Crisis in Mexico }\end{array}$ & $\begin{array}{l}\text { Speculative attack and defaults on Mexico } \\
\text { debts }\end{array}$ \\
\hline 1997-1998 & $\begin{array}{l}\text { Asian Financial } \\
\text { Crisis }\end{array}$ & $\begin{array}{l}\text { Devaluation of currencies and banking crisis } \\
\text { across Asian countries }\end{array}$ \\
\hline 2007-2009 & $\begin{array}{l}\text { Global } \\
\text { Financial Crisis }\end{array}$ & $\begin{array}{l}\text { Started by large loan defaults in subprime } \\
\text { housing mortgages and falling securities } \\
\text { prices that are tied to the housing price } \\
\text { bubbles in the USA; causing severe business } \\
\text { and bank failures globally. }\end{array}$ \\
\hline
\end{tabular}

Source. Wikipedia encyclopedia- financial crisis.

\section{Global Financial Crisis: Differences and Similarities}

The Global Financial Crisis (herein referred as the "Crisis") is claimed as the most severe crisis in the extent and severity of its global impact since World War II (Truman, 2009) or the Great Depression in 1930s (Deepak, 2009). The Crisis surfaced in the US subprime mortgage sector in August 2007 and transformed into a global crisis in September 2008 after the collapse of Lehman Brothers. What is perplexing about the Global Financial Crisis is that it started in the United States of America, the most advanced economy in the world. According to Truman (2009), it was the US that led the way into the crisis when the US economic and financial system experienced deteriorating negative growth. Although the Great Depressions in the 1930s had the global effects, the baffling point was the speed the Crisis simultaneously propagated to other countries and developing 
economies. This somewhat unearthed the powerful domino effects of globalisation and the dark side of financial capitalism not experienced in the previous financial crises.

The extent of the impact in terms of financial loss could be gauged from the sharp upward revisions of the write downs by banks from about US\$ 500 billion in March 2008 to about US\$ 3.5 trillion in October 2009. On the global side, the world GDP is estimated by IMF to have shrunk by $0.8 \%$ and the world trade volume to decline by $12 \%$ (BIS, 2010).

With such magnitude effects, regulators, economists, and scholars continue to identify the fundamental causes of the Crisis, although the immediate factor that triggered the Crisis was the subprime mortgage crisis. Although several writers cite bursting of the US housing bubble as the start of the Crisis, the genesis of the crisis went beyond that to several macroeconomic and microeconomic factors and to human 1 psychology. Some of these factors are subsequently discussed.

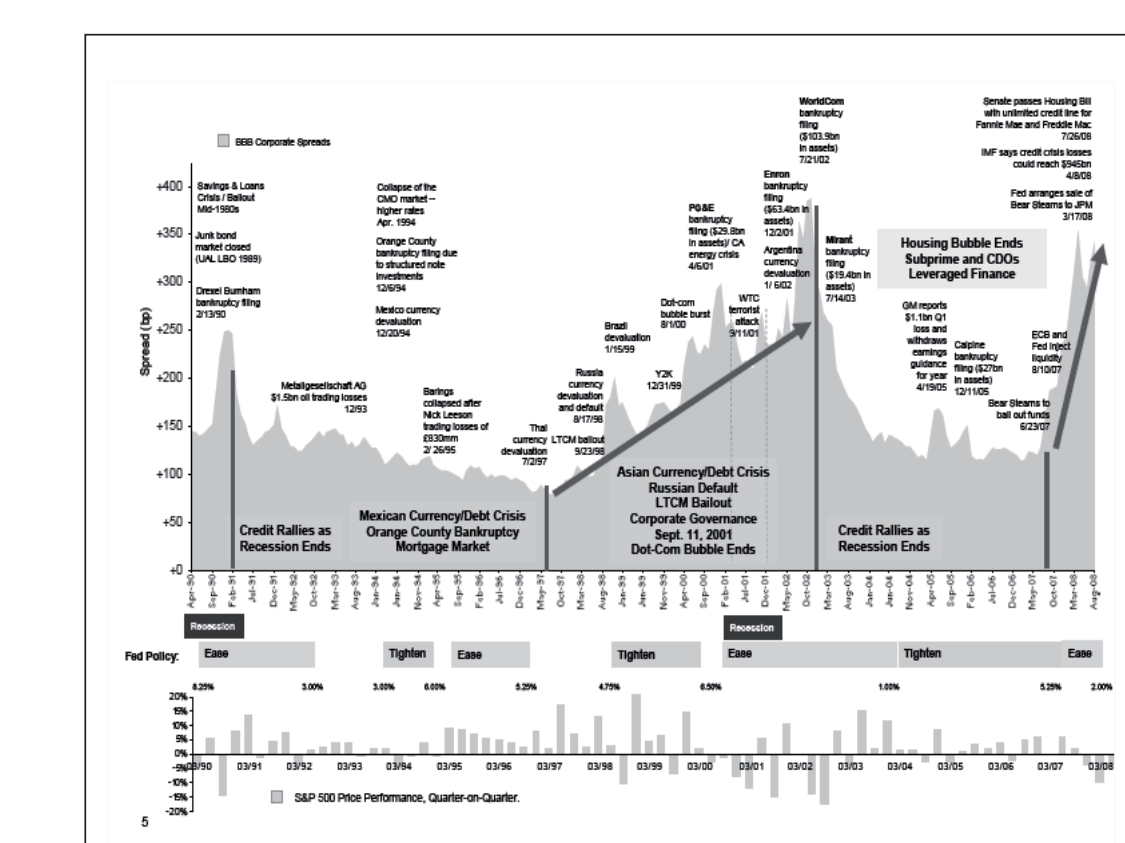

Source. Citigroup Inc September 2008 - Credit Crisis: What, How, Why and When; (Lum et. al, 2008).

Figure 1. Financial Crises. 


\section{Liquidity and easy credits}

One of the key macroeconomic factors was a very high liquidity and cheap money period in the US economy. In the years leading to the Crisis, USA was the recipient of a significant inflow of funds from fastgrowing economies in Asia and oil producing countries. This flow of funds allowed the Federal Reserve to lower interest rates, which contributed to easy availability of bank credits. There was also high accumulation of foreign exchange reserves from developing countries in the US and also in Japan (Truman, 2009). Monetary policies were easy then and interest rates were revised lower several times (due to greater liquidity when US borrowed money abroad to cover its widening trade deficits). Current account deficit increased from 1\% to $5.8 \%$ of GDP. This uphill flow of funds cited by the US Bernanke as "saving glut", the abundant foreign exchange reserves, which flushed the US economy with ample liquidity and easy monetary policies, were quoted as early factors germinating the Crisis.

\section{Excessive leverage and off-balance sheets activities}

The early impact of easy money was initially felt at the micro level. Spurred by more relaxed borrowing terms and procedures, and generous tax incentives, new and existing borrowers took more loans to own properties instead of renting them as in the past, thereby increasing their leverage and excessive use of credits. The leverage level (computed on USA household debt as a percentage of annual disposable income) increased almost $2 x(2: 1)$ to $127 \%$ at the end of 1997 from $77 \%$ in 1990 . By 2009, the leverage ratio was 30:1, that is, total liabilities is $30 \mathrm{x}$ more than the equity value, a far too dangerous leverage level (Benn, 2009). This situation bears similarity with several episodes of the past crises in terms of excessive use of credits, heavy reliance on leverage, and relaxation of credit standards (Reinhart \& Rogoff, 2009). The global dimension of the Crisis is neither new nor unique in this aspect, both on the demand and the supply sides. As the borrowers (representing the demand side) incurred very high gearing with those large loans, the lending financial institutions (which represent the supplier side), simultaneously had high debts in their books as more borrowers faced difficulties to meet their obligations. The accumulation of non-repayments had caused the formation of high credit risk and instantaneously, market risk, as housing and property prices plummeted down on depressed economic conditions.

For many US banks, the resulted high credit risk and market risk during the Crisis have impacted their capital adequacy ratio. This 
means that they had to strengthen their capital base in order to maintain a minimum $8 \%$ capital to risky assets ratio as per Basel requirement. However, the innovative way the banks did to circumvent the requirement, at the same time controlling the risks, was to take the debts off from the banks' Balance sheets. This was achieved by securitising the loans or mortgages into new securities, assigned new risk rating based on the issuer's (the relevant bank's) credit standing and sold them to new investors (RER, 2008). These products such as the mortgage-backed securities, collaterised debt obligations and credit default swaps and other off-balance sheet financing were pertinent to the Crisis, and their presence set it different from the past crises. In terms of risk management, financial innovation creates a new untested territory until the Crisis. Since not many were technically knowledgeable and competent to deal with the new, more complicated risks arising from the innovative products, there were inadequate risk mitigation techniques to deal with them in a timely manner.

\section{"Shadow banking system"}

The US financial system saw active participation of non-banking institutions in the credit markets parallel to the banking system. Unlike banks which are heavily regulated, these financial institutions such as mutual funds, hedge funds, private equity firms, pension funds, insurance companies are not subjected to strict regulations. They represent the "shadow banking system".

Shadow banking institutions operate on high leverage as they borrow on short-term basis to finance long-term, illiquid assets. Since they are not under the control of a formal banking system, their risk taking activities escaped the scrutiny of the regulators. These institutions participated actively in securitised assets at that time prior to the meltdown of the US economy (Farhi, Marcos \& Cintra, 2009). Hence, liquidity risk, market, and credit risk (arising from the mismatch in maturities of assets and liabilities) were not able to be detected until they escalated alarmingly; by then they would contagiously affect other globally linked institutions and companies.

\section{How Malaysia was Impacted}

Malaysia was not spared from the Crisis. Similar to other emerging market economies, the Crisis spread from three channels; confidence, finance, and trade (Deepak, 2009). Lower investors' confidence was felt when the FDI (foreign direct investment) inflows kept contracting 
from the third quarter 2008 until the second quarter of 2009. The reduction in FDI primarily from North, Central, and South America, and Northeast Asia. FDI from the US fell from RM1,100 million in the first quarter 2008 to RM 445million in the first quarter of 2009. On the other hand, outward FDI from Malaysia had risen faster than inward FDI (BNM Report, 2009; UNDP Report, 2009). As of second quarter 2009, investment outflow was RM95,000 million, whilst investment inflow was RM6,899 million. Overall, the situation resulted in negative net FDI inflow for Malaysia and without any additional measures, this was expected to continue until 2010. Among the 10 member Asian countries, Malaysia is currently the only country to suffer negative flows (Thew, 2008). In this respect, several strategies are already in place to step up FDI from other countries such as Middle East and Brazil.

The Malaysian equity market saw the impact of the Crisis in terms of a downward trend of FBMKLCI, which declined to 1000 psychological level from the month of October 2008 (1,100 points) to April 2009 (990.74 points). However, sound regulations and the lack of major players in the local bourse prevented a major market crash and managed to sustain the stock market buoyancy. On renewed and stronger market sentiment, FBMKLCI increased to 1,175 points in July 2009 from 990 level in April 2009 (Mahani and Rajah).

The Malaysian banking sector however did not experience adverse performance. The banks did not invest in toxic assets nor in the subprime mortgage stocks. Thus, with regulations in place and better quality assets (non-performing loan ratio reduced to $2.2 \%$ ), domestic financial institutions remained sound. But the worst affected were export-related sectors, especially the manufacturing sector. As a result of a collapse in demand in developed markets, manufactured exports dropped by $-11.7 \%$ in the fourth quarter of $2008,-19 \%$, and $-14.5 \%$ in the first and second quarter of 2009, respectively. Electronic exports declined significantly by $-44 \%$ and $-34.6 \%$ during the corresponding periods. These contractions took a toll on the Malaysian economy where GDP growth rate declined from $0.1 \%$ in the last quarter of 2008 to $-6.2 \%$ in first quarter of 2009 , and a further drop by $-3.9 \%$ in the second quarter 2009. The grimness of the impact of the Crisis was reflected in the downslide of the Malaysian economy into recession in 2009.

As one of the strategies to revive the economy, the Malaysian government allocated RM7 billion as the first economic stimulus package and an additional RM60 billion as the second stimulus 
package. The RM67 billion package, which accounted for 7\% of 2009 GDP was aimed to stimulate private sector demand and private consumption. To stimulate further liquidity in the financial system, the government has lowered overnight policy rate (OPR) by 25 basis points to $3.25 \%$ in November 2008, a further reduction of 75 basis points and 50 basis points in January and February 2009 to $2 \%$. Statutory Reserve Requirement was lowered by 50 basis points from $4 \%$ to $3.5 \%$. The stimulus package and expansionary monetary policy helped to strengthen domestic and external demand and the Malaysian economy registered a positive growth of $4.5 \%$ for the fourth quarter of 2009 and $10.1 \%$ in the first quarter of 2010. (BNM, 2010). However, as a result of the RM67 billion stimulus package and the severe shortfall in inward FDI as well as the decrease in its exports, Malaysia is facing the biggest fiscal deficit after 22 years. This is an indirect but significant impact of the Crisis on the Malaysian economy.

\section{Lessons Learned}

The Global Financial Crisis exhibits several lessons about the enormous risks originating not only from excessive leverage and deregulation, but also from the spiral effects of globalisation, financial speculation, product innovation, moral hazards, and incentive problems.

More watchful eyes should be in place to monitor and control excessive risk-taking from over leveraging during good times of deregulation and relaxed monetary policies. Excessive debts and over leveraging should not be encouraged by so many "sweeteners"

created by product innovations. The public should be aware that "too good to be true is probably false" (Truman, 2009).

The past crises and the Global Financial Crisis also showed that the seeds of financial risks are actually sown during easy economic conditions, only waiting to lurk during bad times. Hence, it is not only during the bad times but equally important during good times that financial sector supervision and regulation should be strictly kept prudent. If the governance is strictly adhered to, the economy and the public might be less impacted by excessive risk-taking and speculative activities. The alert sign is the asset prices. Rapid upward movements in asset prices would result in inflation in asset prices, causing speculation and price boom. The Crisis showed that financial 
stability could be jeopardised if there is inflationary pressure in asset prices, causing the price bubbles to burst (Deepak, 2009).

Another lesson is the spiral effects of globalisation. Although spared from the credit risk and systemic market risks on the banking assets, several countries experienced adverse effects on exports due to lower global demand from the affected economies (mainly the US and Europe), labour mobility, global wage competition (as the free flow of knowledge allows manufacturing activities to be easily re-located anywhere), price competitiveness, and cross-border contagion effects (Kawai, 2009).

Many researchers, policy makers, and regulators would have summed up the causes of the economic and global financial crisis as the interactive and combined effects of the economic, financial, regulatory, and supervisory policies of the US and other industrial economies.

However, the Crisis highlighted incentive problems and human greed. Most of the large companies that failed in the Global Financial Crisis such as Lehman Brothers, Goldman Sacs, and Citigroup Inc. had very attractive performance-based executive compensation or incentive packages for their top management. They are payable both in the form of cash and equity or stock options. With stock options, the executives tend to gain substantially if they sell their equity when stock price goes up. On the other hand, they would not experience any actual loss if the price falls (unless they exercise the options). In such situations, these executives have greater incentives to indulge in excessive risk-taking activities since they would not incur any material losses if the stock price drops (Berrone, 2008). The corporations did not only experience losses due to moral hazard activities by their executives but also became almost insolvent due to hefty sums paid to these executives, in terms of compensations. As a lesson, the Crisis illustrates that long-established institutions could collapse due to moral hazard activities, including outrageously high incentives designed for self-interests of certain executives.

In a nutshell, how developed a financial market is, how wellstructured financial products are, or how early the warning signals are, there is nothing that could guarantee against the foibles of human nature (Reinhart \& Rogoff, 2008). As past studies have shown that human greed is the nub of all the financial crises (Gahbraith, 1993), it is about time that behind all the sophistications of today's world, we go back to the basics and plain common sense! 


\section{References}

Bank Negara Malaysia (BNM). (2009). BNM Report 2009. Retrived from http://www.bnm.gov.my

Bank Negara Malaysia (BNM) (2010). Quarterly Bulletin - First Quarter 2010. Calendar of Events Jan-March 2010. Retrieved from http://bnm.gov.my

Benn, S. (2009). Lessons of the financial crisis. Council Special Report No.45 (March, 2009). Council on Foreign Relations, Center for Geoeconomics Studies, New York, USA.

Berrone, P. (2008). Current global financial crisis: An incentive problem. Occasional Paper OP-158, October 2008; ISSE Business School- University of Navarra, Barcelona, Spain.

Bank International Settlement (BIS). (2009). The global financial crisis genesis, impact and lessons. Retrieved from http://www.bis.org

Deepak, M. (2009). The global financial crisis-genesis, impact and lessons. International Conference on Frontiers of Interface between statistics and science, organised by Advanced Institute of Mathematics, Statistics and Computer Science and the University of Hyderabad, India.

Galbraith, J. K. (1993). A short history of financial Euphoria. New York, USA: Penguin.

Farhi, M., Marcos., A., \& Cintra, A. (2009). The financial crisis and the global shadow banking system' No 5. Crise du capitalisme financier, Maison des Sciences de l' Homme, Paris Nord, France. Retrieved from http://www.regulation.revus.org

Kawai, Masahiro. (2009). The impact of the global financial crisis on Asia and Asia's responses crisis developments and long-

term global responses: Insights from Asia and Europe, AEEF
Conference, Kiel, Asian Development Bank Institute.

term global responses: Insights from Asia and Eu
Conference, Kiel, Asian Development Bank Institute.

- Lum, C. A., Ramalingam, Tan, L. H., \& Sama, K. V. J. M (2008). Global financial crisis, causes and effects. (Unpublished master's thesis).

Abidin, M. Z., \& Rasiah, R. (2009). Global financial crisis and the impact on Malaysia. UNDP Report 2009, United Nations Development Programme, Damansara Heights, Kuala Lumpur. Retrieved from http://www.undp.org.my

Reinhart, C., \& Rogoff, K. S. (2009). This time is different: 8 centuries of financial folly. Princeton University Press.

Rogue Economist (RER). (2008). Speculation on bank strategy: Capital adequacy perspective. Retrieved from http://www. rogueeconomistrants.blog spots.com

Thew, T. H. (2008). South East Asia: Impact of financial crisis. Global Voices blog. 
Truman, E.M. (2009). The global financial crisis: Lessons learned and challenges for developing countries. Peterson Institute for International Economics, Remarks at the Eighteenth Cycle of Economics, Banco de Guatemala, June 16, 2009. 